\title{
A Phage-associated Murein Hydrolase in Streptococcus pneumoniae Infected with Bacteriophage Dp-1
}

\author{
By PEDRO GARCIA, ${ }^{1}$ ERNESTO GARCIA, ${ }^{1}$ CONCEPCION RONDA, ${ }^{1}$ \\ RUBENS LOPEZ ${ }^{1}$ AND ALEXANDER TOMASZ ${ }^{2 *}$ \\ ${ }^{1}$ Instituto de Inmunologia y Biología Microbiana, (CSIC) Madrid, Spain \\ ${ }^{2}$ The Rockefeller University, 1230 York Avenue, New York 10021, U.S.A.
}

(Received 19 May 1982; revised 29 July 1982)

\begin{abstract}
A phage-associated murein hydrolase activity capable of degrading pneumococcal cell walls was isolated and purified to homogeneity from the phage-induced lysate of an autolysis-defective pneumococcal mutant infected with the bacteriophage Dp-1. Some properties of the enzyme resembled those of the wild-type (host) pneumococcal murein hydrolase: cell walls prepared from ethanolamine-grown pneumococci were resistant to the enzyme; the activity was inhibited by the Forssman antigen and was sensitive to proteolytic enzymes. The phage-associated enzyme was not inhibited by antiserum prepared against the purified pneumococcal murein hydrolase; the activity was stimulated by reducing agents and was partially inhibited by cardiolipin. The subunit molecular weight of the phage-associated enzyme was somewhat smaller $(31000)$ than that of the pneumococcal hydrolase (35000). This appears to be the first description of a phage-associated murein hydrolase activity in pneumococci.
\end{abstract}

\section{INTRODUCTION}

Bacterial murein hydrolases, enzymes capable of hydrolysing a variety of covalent bonds in the bacterial murein (peptidoglycan), have been implicated in a number of important biological phenomena such as enlargement of the cell wall, separation of daughter cells during cell division (Tomasz et al., 1975), and penicillin-induced lysis and death of bacteria (Tomasz, 1979). It has also been suggested that the release of progeny bacteriophage from pneumococci infected with the phage Dp-1 may involve the triggering of host autolytic enzyme by some phage product, since autolysis-defective pneumococci were found to be resistant to lysis by Dp-1 (Ronda et al., 1977). Resistance to phage-induced lysis was demonstrated in pneumococci grown in ethanolamine-containing medium (a condition known to suppress the activity of the pneumococcal murein hydrolase) and in bacteria grown under a variety of physiological conditions that inhibit pneumococcal autolysis (e.g. growth at low $\mathrm{pH}$, in the presence of trypsin or high concentrations of the Forssman antigen (Höltje \& Tomasz, 1975; Ronda et al., 1977); these conditions also prevented release of phage particles.

The starting point of this investigation was an attempt to understand the peculiar behaviour of lysis-defective pneumococcal mutants during infection. Productive infection of such mutants required relatively high multiplicity of infection (higher than 1 phage per viable cell). Nevertheless, with the higher phage input, infected cultures did undergo complete lysis accompanied by extensive degradation of the bacterial cell wall. Upon more detailed analysis of such lysates we detected the appearance of a murein hydrolase activity that seems to differ from the pneumococcal amidase in several properties. In this communication we describe the isolation, purification and partial characterization of this enzyme. 


\section{METHODS}

Streptococcus pneumoniae strain $\mathbf{R}_{6}$ is a derivative of the Rockefeller University Laboratory wild-type strain $\mathrm{R}_{36} \mathrm{~A}$. Strain $\mathrm{cwl}$ (Lacks, 1970) is a mutant of $\mathrm{R}_{6}$ defective in the major autolysin ( $N$-acetyl-muramyl-L-alanyl amidase) present in the wild-type bacteria (Mosser \& Tomasz, 1970).

Bacteria containing teichoic acids with either choline or ethanolamine residues, were produced by growth for more than 20 generations in medium containing the appropriate amino alcohol, as previously described (Tomasz et al., 1975). Isolation and purification of bacteriophage Dp-1 have been described elsewhere (Lopez et al., 1977). Chemically defined (Cden) growth medium, semisynthetic (C) medium (Tomasz, 1966; Tomasz, 1970) and the preparation of autolysin (Höltje \& Tomasz, 1976) have been described in detail in previous communications.

Cell walls labelled with $\left[\right.$ methyl $\left.{ }^{3} \mathrm{H}\right]$ choline (specific activity $60 \mathrm{Ci} \mathrm{mmol}^{-1}, 2 \cdot 2 \mathrm{TBq} \mathrm{mmol}{ }^{-1}$ ) or $\left[2 \cdot{ }^{14} \mathrm{C}\right]$ ethan-1ol-2-amine hydrochloride (specific activity $44 \mathrm{mCi} \mathrm{mmol}^{-1}, 1.6 \mathrm{GBq} \mathrm{mmol}^{-1}$ ) were prepared by biosynthetic labelling of the bacteria (Mosser \& Tomasz, 1970). All chemicals used were commercial, available analytical grade reagents. Radioactive materials were purchased from Amersham.

The standard assay for phage-induced lytic activity was similar to that previously described for the pneumococcal amidase (Höltje \& Tomasz, 1976). In short: $10 \mu \mathrm{l}\left[{ }^{3} \mathrm{H}\right]$ choline-labelled cell walls $(0 \cdot 15 \mathrm{mg}$ dry wt per $10^{6}$ c.p.m. $\mathrm{ml}^{-1}$ ) was mixed with $100 \mu \mathrm{l}$ bacterial lysate and $100 \mu \mathrm{l} 0.02 \mathrm{M}$-phosphate buffer, $\mathrm{pH} 6.9$, and the mixture was incubated for 1 to $4 \mathrm{~h}$ at $37^{\circ} \mathrm{C}$. The reaction was stopped by adding $20 \mu \mathrm{l} 38 \%(\mathrm{v} / \mathrm{v})$ formaldehyde and $20 \mu 10.4 \%(\mathrm{w} / \mathrm{v})$ bovine serum albumin (Armour fraction IV). Samples were centrifuged in a microcentrifuge at $10000 \mathrm{~g}, 15 \mathrm{~min}$. The radioactivity in $200 \mu \mathrm{l}$ portions of the supernatants was determined using Ready Solv (Beckman) scintillation fluid and counted in an Intertechnique scintillation counter.

Purification of lytic enzyme. All purification steps for phage associated lysin were carried out at $4{ }^{\circ} \mathrm{C}$.

Step 1: Preparation of crude extract. C medium (21) containing $1 \mathrm{mg}$ Difco yeast extract $\mathrm{ml}^{-1}$ was inoculated with an overnight culture of strain $\mathrm{cwl}$ to give a cell density of $2 \times 10^{7}$ c.f.u. $\mathrm{ml}^{-1}$. The culture was grown at $37^{\circ} \mathrm{C}$ to a cell density of $6.2 \times 10^{7}$ c.f.u. $\mathrm{ml}^{-1}$. Purified Dp-1 was added at a multiplicity of infection (m.o.i.) of 5. After $60 \mathrm{~min}$ incubation 2-mercaptoethanol was added to a concentration of $10 \mathrm{mM}$ and the incubation continued until complete lysis occurred (about $90 \mathrm{~min}$ after the addition of phage). The lysate was cooled on ice and the cellular debris removed by centrifugation $(6000 \mathrm{~g}, 20 \mathrm{~min})$ at $4{ }^{\circ} \mathrm{C}$.

Step 2: Precipitation with polyethyleneglycol $(P E G)$. Supernate containing crude enzyme was made $0.5 \mathrm{M}$ with respect to $\mathrm{NaCl}$ and $\mathrm{PEG} 6000$ was added to a final concentration of $10 \%(\mathrm{w} / \mathrm{v})$. After standing $16 \mathrm{~h}$ at $4{ }^{\circ} \mathrm{C}$, the precipitate was collected by centrifugation $(10000 \mathrm{~g}, 15 \mathrm{~min})$ and the pellet was resuspended in $40 \mathrm{ml}$ TBT buffer [0.5 $\mathrm{M}-\mathrm{NaCl}, 10 \mathrm{mM}-\mathrm{Tris} / \mathrm{HCl}$ ( $\mathrm{pH} 7-5$ ), $10 \mathrm{~mm}-\mathrm{MgCl}_{2}$ and $10 \mathrm{~mm}-2$-mercaptoethanol].

Step 3: Band centrifugation in $\mathrm{CsCl}$. The pellet resuspended in TBT was layered on to the top of a three-step CsCl gradient prepared in polyallomer tubes as follows: $3 \mathrm{ml} \mathrm{CsCl}$ dissolved in TBT buffer to a density (d) of $1.7 \mathrm{~g} \mathrm{ml}^{-1}$; $10 \mathrm{ml}$ at $\mathrm{d}=1.5 \mathrm{~g} \mathrm{ml}^{-1}$ and $10 \mathrm{ml}$ at d $=1.3 \mathrm{~g} \mathrm{ml}^{-1}$. After centrifugation at $25000 \mathrm{~g}$ in an AH 627 ultracentrifuge for $150 \mathrm{~min}$ fractions were collected (by puncturing the bottom of the centrifuge tubes) and these were tested for lytic activity and for p.f.u.

Step 4: Equilibrium centrifugation in $\mathrm{CsCl}$. Fractions from step 3 showing lytic activity were pooled, the density adjusted to $1.3 \mathrm{~g} \mathrm{ml}^{-1}$ by the addition of $\mathrm{CsCl}$ and the preparation was then ultracentrifuged at $40000 \mathrm{~g}$ in an A-841 rotor at $4{ }^{\circ} \mathrm{C}$ for $60 \mathrm{~h}$. Fractions $(0.5 \mathrm{ml})$ were collected and tested for lytic activity.

Step 5. The material collected from the active fractions of Step 4 was pooled, treated with Triton X-100 (final concentration $0 \cdot 1 \%, \mathrm{w} / \mathrm{v}$ ) for $60 \mathrm{~min}$ at $4{ }^{\circ} \mathrm{C}$ and was applied to a Bio-Gel P-60 (Bio-Rad, 100-200 mesh) column $(4.2 \times 85 \mathrm{~cm})$. The column was eluted with $0.02 \mathrm{M}$-sodium phosphate buffer at pH 7.0 containing $10 \mathrm{~mm}-2-$ mercaptoethanol and $0.05 \%(\mathrm{w} / \mathrm{v})$ Triton X-100 at a flow rate of $15 \mathrm{ml} \mathrm{h}^{-1}$. Fractions $(8.7 \mathrm{ml} \mathrm{each})$ were collected and enzyme activity was determined in $100 \mu \mathrm{l}$ of each fraction. Active fractions were pooled $(25 \mathrm{ml})$ and concentrated to a volume of $3 \mathrm{ml}$ using a PM-10 Diaflo membrane.

Analysis of fractions. Samples of some of the fractions collected from the CsCl equilibrium gradient (Step 4) were dialysed against $0 \cdot 1 \mathrm{M}$-ammonium acetate $(\mathrm{pH} 7 \cdot 0)$. These samples were mixed $(1: 1, \mathrm{v} / \mathrm{v}) \mathrm{with} 2 \%(\mathrm{w} / \mathrm{v})$ potassium phosphotungstate ( $\mathrm{pH} \mathrm{7.0)}$ and a drop was placed on carbon-coated grids for $5 \mathrm{~min}$; excess stain was blotted off and the grids were placed in a desiccator. Samples were examined in a Philips 300 electron microscope at an accelerating voltage of $80 \mathrm{kV}$.

SDS-PAGE was performed at room temperature with $10 \%(\mathrm{w} / \mathrm{v})$ gels in $0 \cdot 1 \%(\mathrm{w} / \mathrm{v})$ SDS $\mathrm{pH} 7 \cdot 2$ according to Weber et al. (1972). The preparation of pneumococcal Forssman antigen has been previously described (Briles \& Tomasz, 1973). The preparation of rabbit antiserum against the purified pneumococcal amidase was described in a previous communication (Garcia et al., 1982).

\section{RESULTS}

\section{Phage-induced lysis of the autolysis-defective pneumococcal mutant}

The basic observation that served as a starting point for these studies is illustrated by Fig. 1 . Infection of the autolysis-defective pneumococcal mutant $c w l$ with phage Dp-1 only results in 


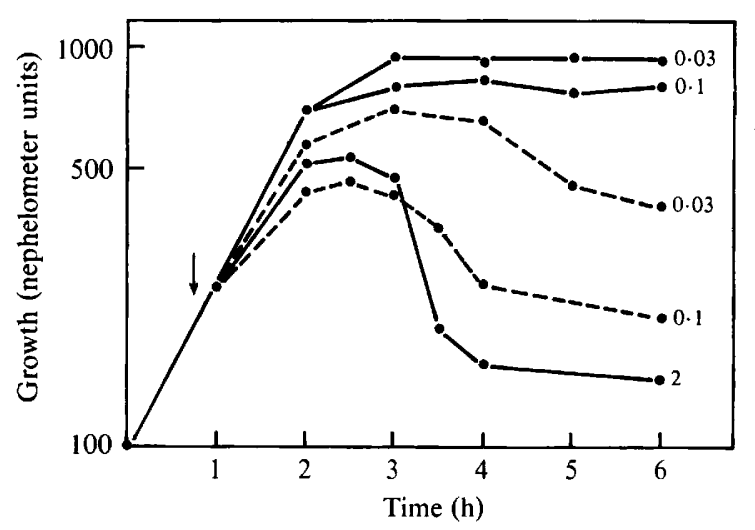

Fig. 1. Phage-induced lysis of autolysin-defective and wild-type cultures as a function of the m.o.i. Both the mutant (-O) and the wild-type (-.- bacteria were grown in $\mathrm{C}+\mathrm{Y}$ medium, infection was done at the time indicated by the arrow at the m.o.i. values indicated by the numbers on the curve. Growth and lysis were followed by nephelometry.

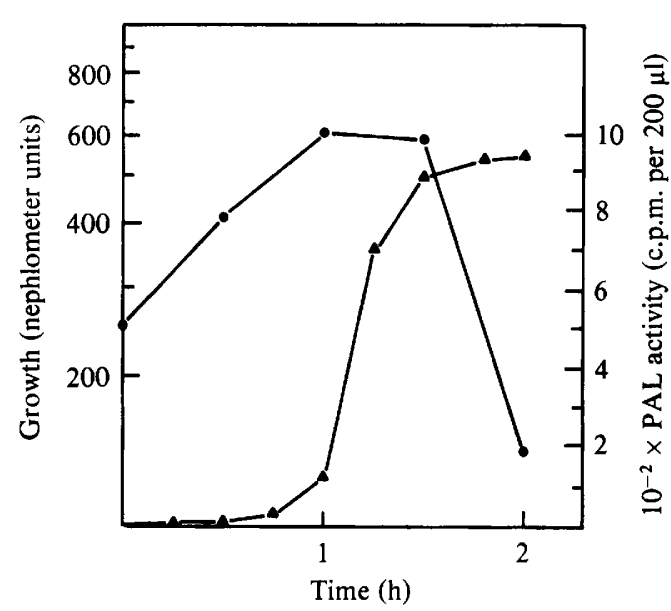

Fig. 2. Liberation of the PAL after phage Dp-1 infection of $c w 1$. A culture of the autolysin-defective mutant was infected at a cell density of $6.2 \times 10^{7}$ c.f.u. $\mathrm{ml}^{-1}$ with $\mathrm{Dp}-1(\mathrm{~m} . \mathrm{o} . \mathrm{i} .=5)$. At different times, samples were taken, centrifuged and the presence of the lytic activity $(\boldsymbol{\Delta})$ in the supernatant fluid was investigated using $\left[{ }^{3} \mathrm{H}\right]$ choline labelled cell walls, as described in the Methods. Growth (O) and lysis were followed by nephelometry.

eventual culture lysis if the bacteria were infected at a m.o.i. higher than 1 phage per bacterial cell. In contrast, wild-type (autolysis-prone) cultures would undergo phage-induced lysis even after infection at low phage to cell ratios.

The lysis of Dp-1 infected $c w 1$ was surprising since these bacteria were shown to contain greatly lowered specific activity of the autolytic amidase $(\sim 0.1 \%$ of the specific activity in wildtype extracts) and other agents capable of triggering autolysis of the wild type bacteria (e.g. detergents, cell wall inhibitors, hypertonic media, etc.) were all found to be ineffective in causing lysis of the mutant cells (Tomasz \& Waks, 1975).

The appearance of a cell wall hydrolysing activity in supernates from cultures of the $c w l$ mutant infected with Dp-1 at m.o.i. of 5 is shown in Fig. 2. Murein hydrolase activity in the supernatant was detected prior to the onset of lysis. There was no detectable activity in the supernates of uninfected control $c w l$ cultures and sonicated extracts of control $c w l$ cultures showed only the low degree of activity characteristic of such mutants. 
Table 1. Purification of pneumococcal phage-associated lysin

$\begin{array}{lcccccc}\text { Purification step } & \begin{array}{c}\text { Volume } \\ (\mathrm{ml})\end{array} & \begin{array}{c}\text { Total } \\ \text { protein } \\ (\mathrm{mg})\end{array} & \begin{array}{c}\text { Total enzyme } \\ \text { activity } \\ \text { (units) }^{*}\end{array} & \begin{array}{c}\text { Specific enzyme } \\ \text { activity } \\ \text { (units } \mathrm{mg}^{-1} \text { ) }\end{array} & \begin{array}{c}\text { Recovery } \\ (\%)\end{array} & \begin{array}{c}\text { Purification } \\ \text { factor }\end{array} \\ \text { extract } & 2000 & 280 & 260000 & 928 \cdot 6 & 100 & 1 \\ \text { EG precipitate } & 40 & 41 \cdot 40 & 210650 & 5088 \cdot 2 & 80 & 5 \cdot 5 \\ \text { entrifugation I } & 56 \cdot 5 & 27 \cdot 10 & 130500 & 4787 \cdot 0 & 50 & 5 \cdot 2 \\ \text { Centrifugation II } & 12 \cdot 0 & 12 \cdot 30 & 125000 & 10162 \cdot 0 & 48 \cdot 1 & 10 \cdot 9 \\ \text { P-60 chromatography } & 3 \cdot 0 & 0 \cdot 10 & 67500 & 675000 \cdot 0 & 26 & 3755 \cdot 0\end{array}$

followed by AMICON PM-10

filtration

* One unit of PAL activity was defined as the amount that catalyses the hydrolysis (solubilization) of $1 \mu \mathrm{g}$ cell wall ( 815 c.p.m.) at $37^{\circ} \mathrm{C}$ in $30 \mathrm{~min}$.

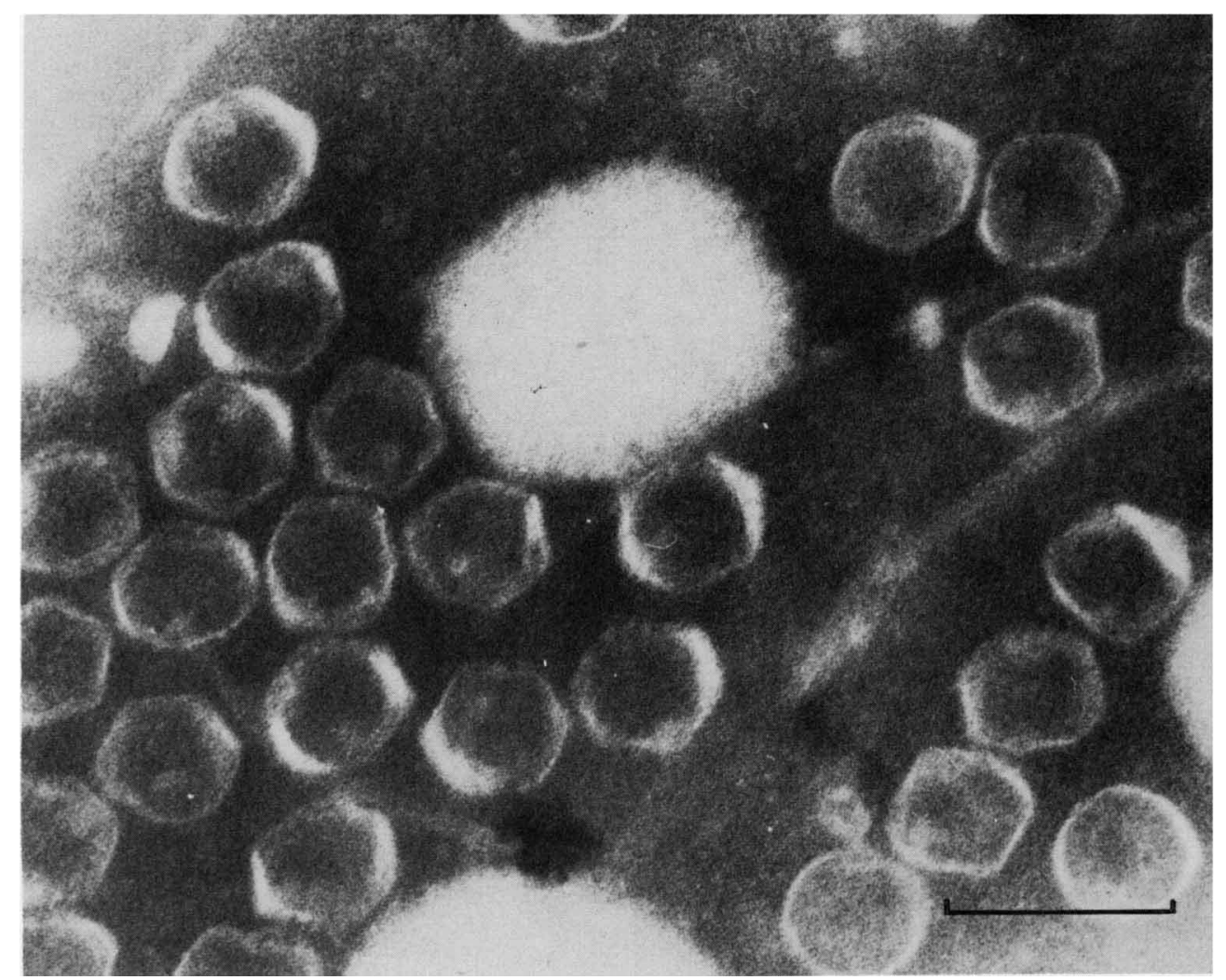

Fig. 3. Electron micrograph of phage-like particles. The preparation was made from fraction 17 of a $\mathrm{CsCl}$ gradient. The bar marker represents $100 \mu \mathrm{m}$.

\section{Purification of the phage-associated murein hydrolase}

Preliminary experiments indicated that the cell wall hydrolysing activity of lysates could be greatly stimulated by reducing agents (5- to 10 -fold stimulation in the presence of $10 \mathrm{~mm}-2-$ mercaptoethanol and $10 \mathrm{~mm}$-DTT, respectively); the activity (measured in the presence of $10 \mathrm{~mm}-\mathrm{DTT}$ ) was stable in $1 \%(\mathrm{w} / \mathrm{v})$ Triton X-100 but was inhibited (or destroyed) by $0 \cdot 1 \%(\mathrm{w} / \mathrm{v})$ deoxycholate, SDS or sarcosyl NL-97.

The purification procedure was described in detail in Methods and data on the specific enzyme activities, recoveries and factors of purification in the various steps of the procedure are summarized in Table 1 . In essence, Dp-1-induced lysates of the $c w 1$ mutant culture were treated 

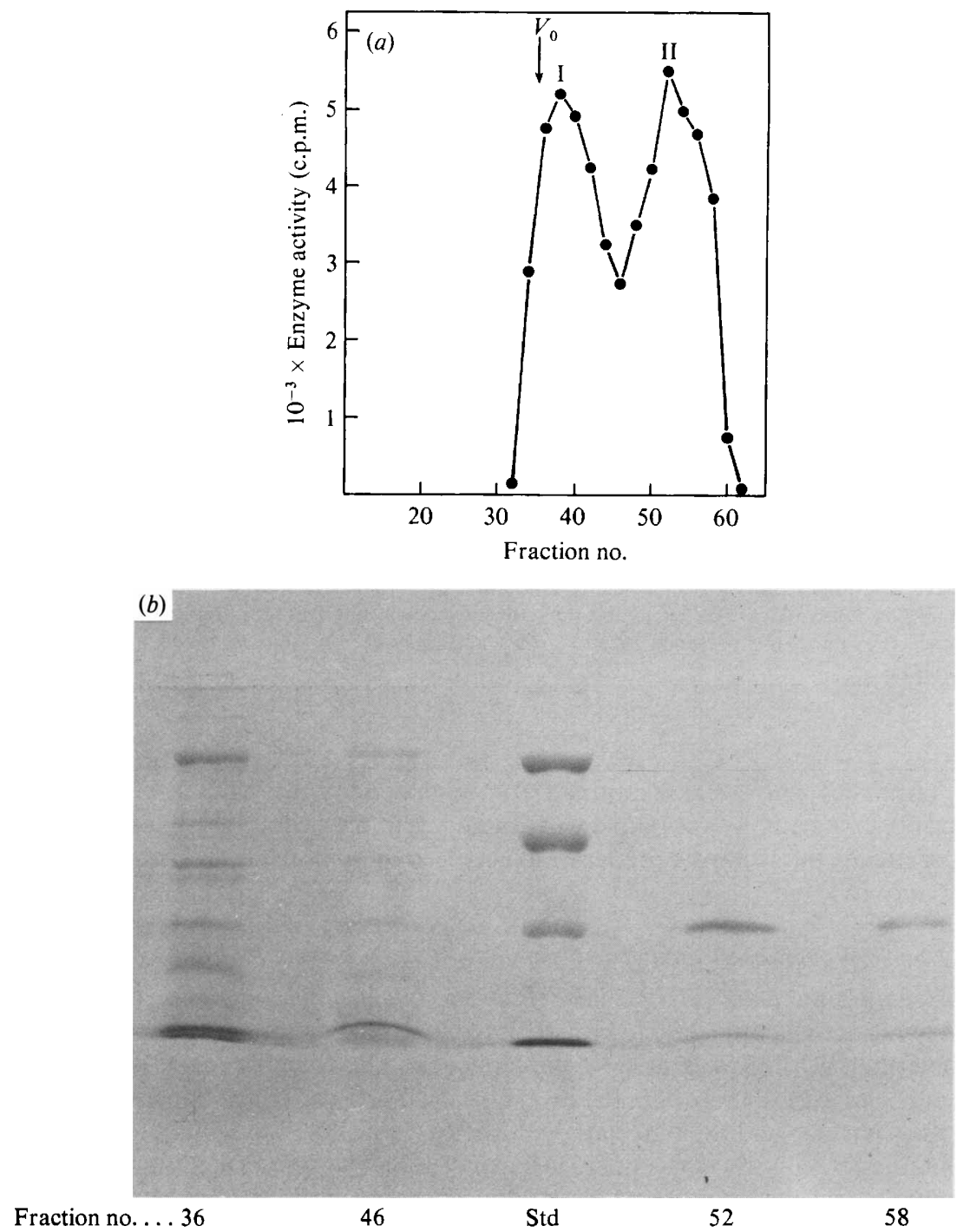

Fig. 4. Purification of PAL activity on Biogel P-60 (see Methods). (a) Lytic activity (O). Peaks I and II were separated and peak II was used in the further analysis of PAL. $V_{0}$ represents the void volume. (b) The analysis of fractions by SDS-PAGE. The molecular weight standards (Std) were bovine serum albumin (mol. wt 68000); ovalbumin (45000); pancreatic DNAase (31000). The fastest moving band is the tracking dye. Gels were stained with Coomassie blue.

with PEG plus sodium chloride which precipitated both the enzyme activity as well as the immature and mature phage particles. Next, mature phage and enzyme activity were separated from one another in the presence of $10 \mathrm{mM}$-2-mercaptoethanol on a three-step gradient of $\mathrm{CsCl}$. Lytic activity peaked in fraction $18\left(\rho \sim 1.22 \mathrm{~g} \mathrm{~cm}^{-3}\right)$ and p.f.u. in fraction $9\left(\rho \sim 1.53 \mathrm{~g} \mathrm{~cm}^{-3}\right)$. During further purification of the enzyme fraction by centrifugation to equilibrium in $\operatorname{CsCl}(\rho=$ $1.3 \mathrm{~g} \mathrm{~cm}^{-3}$ ), PAL activity banded at $\rho=1.26 \mathrm{~g} \mathrm{~cm}^{-3}$.

Peak fractions in Fig. 4 from the equilibrium centrifugation examined by electron microscopy showed the presence of empty phage heads and tails (Fig. 3). The pooled fractions were treated with Triton X-100 (and $10 \mathrm{~mm}$-2-mercaptoethanol) and were applied to a Biogel P-60 column which was eluted with buffer. Of the two peaks of enzyme activity the first one (close to the void volume) still contained the empty phage particles while the second peak of enzyme activity was free of such structures (Fig. 4). Fractions in this second peak were pooled, concentrated by 


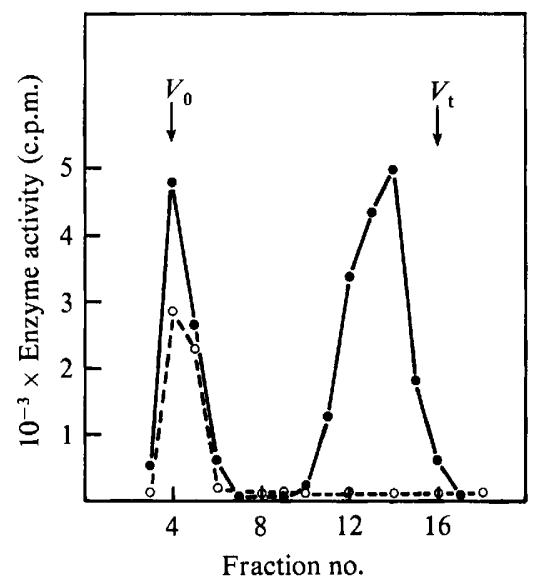

Fig. 5. Gel filtration on Biogel A-5m of PAL obtained in the absence or in the presence of reducing agents. Active fractions from the second $\mathrm{CsCl}$ gradient were applied to a $15 \times 0.5 \mathrm{~cm}$ column of agarose. Fractions of $0.3 \mathrm{ml}$ were collected and the lytic activity was determined. Preparation obtained in the absence $(O)$ or in the presence $(O)$ of 2 -mercaptoethanol. $V_{0}$, void volume; $V_{t}$, complete retention volume.

ultrafiltration (Amicon) and were examined for homogeneity by SDS-PAGE. A single Coomassie blue positive band was obtained with an apparent molecular weight of about 31000 . This electrophoretically pure enzyme preparation was used for a more detailed characterization of the enzyme activity.

\section{Some properties of the purified phage-associated murein hydrolase}

Attempts to separate the phage-like particles from the murein hydrolase activity. During the purification enzymic activity appeared to be associated with particles that resembled empty Dp1 particles. Nevertheless, the low density of these particles and the absence of lytic activity in mature intact particles led to a more detailed investigation of a possible relationship between the intact, low density particle and the lytic activity. Analysis by SDS-PAGE (data not shown) of the particles obtained by equilibrium centrifugation in $\mathrm{CsCl}$ (step 4 of purification) revealed that these particles contained the main structural proteins present in the mature particles of Dp-1 (Lopez et al., 1977). In addition, a protein band identical in electrophoretic mobility to that of the murein hydrolase was also present.

The nature of association between the enzyme and the particles was studied. Preparations of PAL purified in the presence of 2-mercaptoethanol on Biogel A-5m (Bio Rad, 200-400 mesh) showed two peaks, one in the void volume and another in the included volume of the column. Only the first peak which contained the phage-like particles was present in preparations that were made in the absence of 2-mercaptoethanol (Fig. 5). The composite Fig. 6 summarizes some of the properties of the purified enzyme.

Inhibitors of PAL activity. The pneumococcal Forssman antigen was found to be a powerful inhibitor of PAL, $50 \%$ inhibition being achieved by $1 \mu \mathrm{g}$ Forssman antigen $\mathrm{ml}^{-1}$ (Fig. 7). Relatively high concentrations of cardiolipin $\left(>50 \mu \mathrm{g} \mathrm{ml}^{-1}\right)$ also caused a maximum of $50 \%$ inhibition. Antiserum against the pneumococcal autolysin was ineffective as an inhibitor of PAL (not documented). The PAL activity was insensitive to treatment with phospholipase C, glucosidase, pancreatic RNAase and DNAase, while trypsin, pronase $\mathrm{E}$ and proteinase $\mathrm{K}$ each reduced PAL activity by about $90 \%$ (treatments by $50 \mu \mathrm{g}$ enzyme $\mathrm{ml}^{-1}$ at $37^{\circ} \mathrm{C}$ for $30 \mathrm{~min}$ ). PAL activity was virtually unaffected by $10^{-2} \mathrm{M} \mathrm{LiCl}, \mathrm{NaCl}$ or $\mathrm{KCl}$. Similar concentrations of $\mathrm{MgCl}_{2}$ caused moderate inhibition $\left(50-60 \%\right.$ ) while $\mathrm{CaCl}_{2}, \mathrm{FeSO}_{4}, \mathrm{CuSO}_{4}, \mathrm{ZnCl}_{2}$ or $\mathrm{HgCl}_{2}$ were powerful inhibitors (less than $10 \%$ residual activity). 


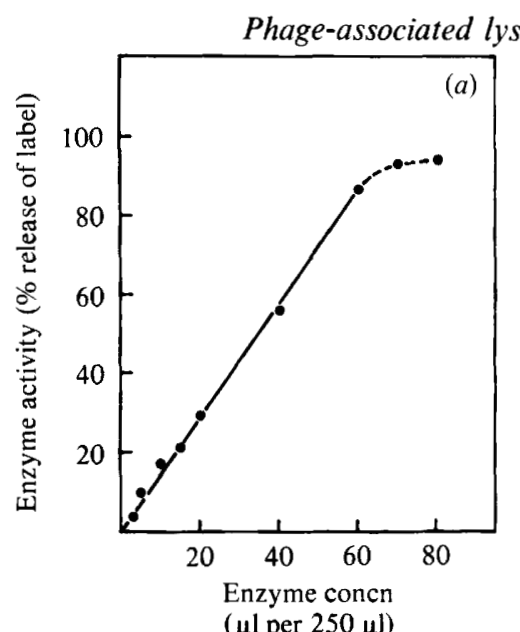

sin in pneumococci

$(\mu 1$ per $250 \mu 1)$
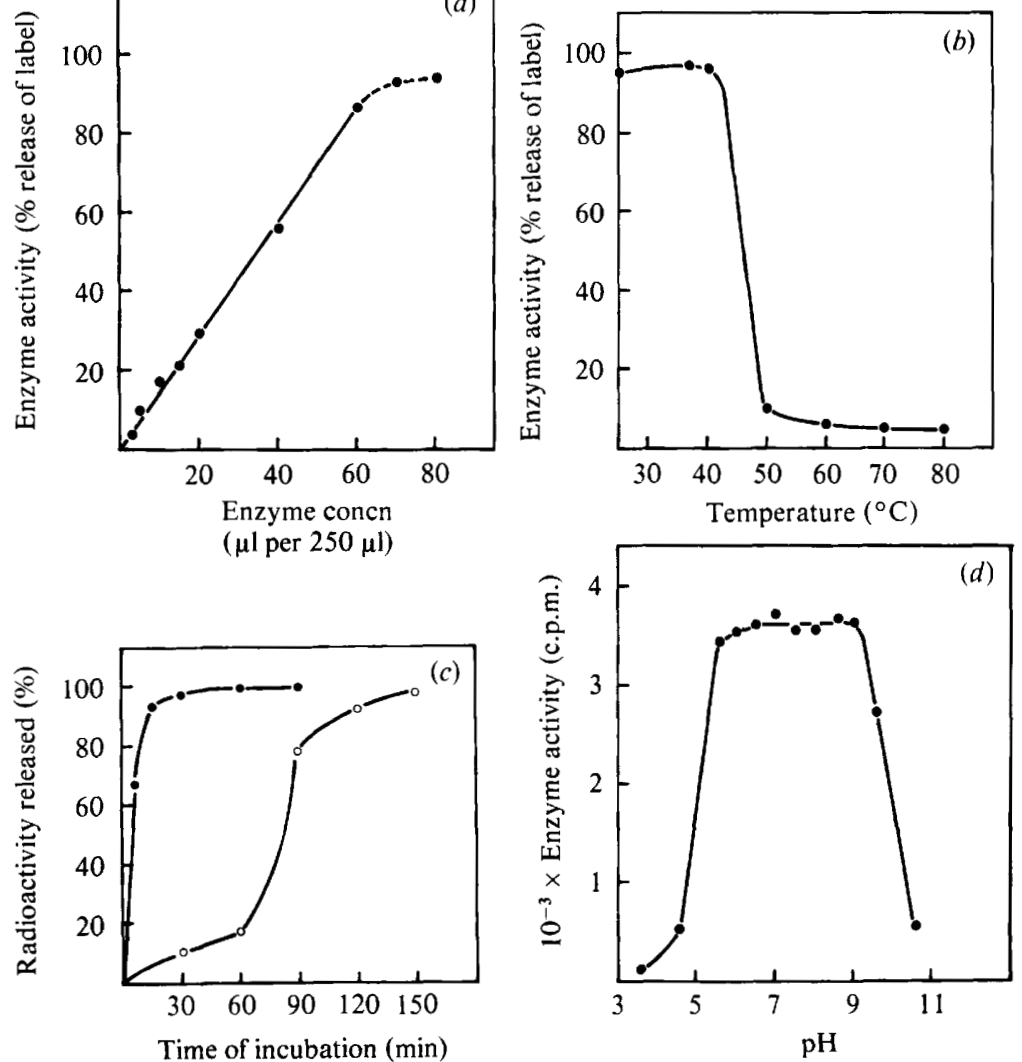

Fig. 6. Some properties of the purified PAL. Dependence of enzyme activity on enzyme concentration $(a)$ and effect of the temperature $(b)$, reducing agents $(c)$ and $\mathrm{pH}(d)$ on the enzyme activity were determined. (a) Enzyme reaction was measured using various concentrations of purified PAL and a fixed amount of $\left[{ }^{3} \mathrm{H}\right]$ choline-labelled cell walls. $(b)$ Samples of the purified enzyme were incubated for $5 \mathrm{~min}$ at the indicated temperatures. The solutions were cooled and the residual activity was measured by the standard method of assay. Activities are shown as percentages of the activity of unincubated enzyme. (c) $\left[{ }^{3} \mathrm{H}\right]$ choline-labelled cell walls were incubated at $37^{\circ} \mathrm{C}$ with $5 \mu$ purified PAL in the presence $(O)$ or in the absence $(O)$ of $10 \mathrm{~mm}$-DTT or $10 \mathrm{~mm}$-2-mercaptoethanol. Samples were taken at different times, centrifuged and the supernatants were analysed for radioactivity. $(d)$ Dependence of the activity of PAL on pH. Purified PAL ( $5 \mu \mathrm{l}, 265$ units) was tested at various pH values; buffers (sodium acetate; Tris/maleate; sodium phosphate/Tris and sodium bicarbonate) were used to produce the appropriate $\mathrm{pH}$ values. The chemical nature of these buffers did not influence enzyme activity.

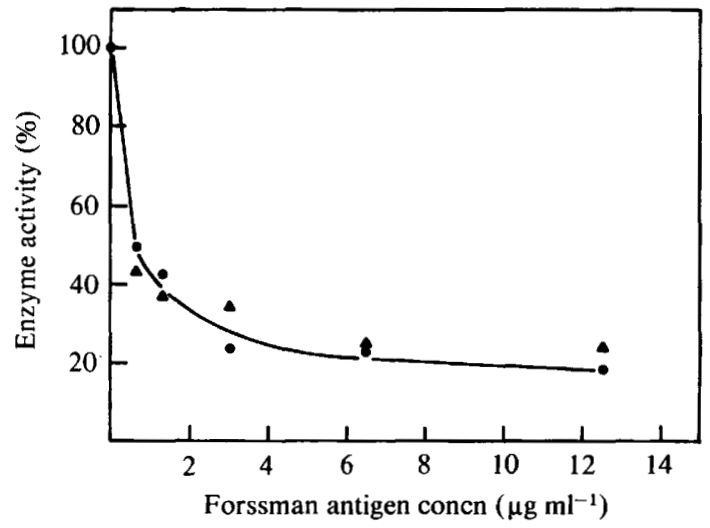

Fig. 7. Inhibition of PAL by the Forssman antigen. Forssman antigen was added in amounts indicated in the graph to reaction mixtures containing either PAL $(\mathcal{O})$ or amidase $(\boldsymbol{\Lambda})$. 


\section{DISCUSSION}

The phage-associated murein hydrolase resembled the pneumococcal amidase in several properties. Cell walls prepared from ethanolamine-grown pneumococci labelled with radioactive ethanolamine were undigested by PAL (data not shown), as previously found for the pneumococcal amidase (Höltje \& Tomasz, 1975). Both pneumococcal amidase (Höltje \& Tomasz, 1976) and the phage-associated enzyme were strongly inhibited by the pneumococcal Forssman antigen and were sensitive to proteolytic enzymes. On the other hand, the two enzymes were clearly different with respect to several other properties, namely: (i) antiserum prepared against the pneumococcal enzyme did not inhibit the phage-associated enzyme; (ii) a partial inhibition occurred with cardiolipin; (iii) neither the purified nor the crude form of the pneumococcal enzyme showed stimulation of activity by reducing agents; (iv) the subunit molecular weight of the pneumococcal enzyme was somewhat higher (35000) (Höltje \& Tomasz, 1976) than that of the phage-associated enzyme (31000). We feel that the weight of evidence is in favour of the interpretation that the autolysis-defective pneumococcal mutant is lysed by a new, phage-induced murein hydrolase. Nevertheless, the alternative interpretation, namely, stabilization and/or activation of the residual host activity by some phage product cannot be rigorously excluded. The strongest evidence available against this interpretation seems to be the lack of inhibition of the phage-associated enzyme by antibody prepared against the purified pneumococcal amidase. Immunodiffusion tests did not yield any evidence for an interaction between such antibody preparations and the phage-associated lysin (data not shown). However, it is conceivable that the residual amidase activity in the mutant cells is somehow altered by a phage-dependent process (proteolysis?) in such a manner that reactivity at the antigenic site(s) in the enzyme protein becomes modified. Biochemical comparison of the cell wall fragments produced by the phage-associated hydrolase versus the host murein hydrolase should provide a more critical test of these possibilities.

Careful tests with purified Dp-1 phage preparations showed no detectable hydrolase activity, assayed as release of label from radioactively labelled cell wall preparations. Thus, the hydrolase does not seem to be a component of mature phage particles. In this respect, the enzyme resembles the phage-associated murein hydrolase of group A streptococci infected with phage A 25 (Hill \& Wannamaker, 1981).

We thank Professor Antonio Portoles for his support. We also thank Mr E. Blanco and Mr J. Blanco for the electron microscopy. This work has been supported by grant 3067-79 of the Comission Asesora para el Desarrollo de la Investigacion Cientifica y Tecnica and by grant AI 16170 from the National Institutes of Health, US Public Health Service. P. G. received a Predoctoral Fellowship from Caja de Ahorros y Monte de Piedad de Madrid.

\section{REFERENCES}

Briles, E. B. \& Tomasz, A. (1973). Pneumococcal Forssman antigen: a choline-containing lipoteichoic acid. Journal of Biological Chemistry 248, 6394-6397.

Garcia, E., Rojo, J. M., Garcia, P., Ronda, C., LOPEZ, R. \& Tomasz, A. (1982). Preparation of antiserum against the pneumococcal autolysin inhibition of autolysin activity and some autolytic processes by the antibody. FEMS Microbiology Letters 14, 133-136.

Hill, J. R. \& WanNamaker, L. W. (1981). Identification of a lysin associated with a bacteriophage (A 25) virulent for Group A streptococci. Journal of Bacteriology 145, 696-703.

HöltJE, J. V. \& Tomasz, A. (1975). Biological effects of lipoteichoic acids. Journal of Bacteriology 124, 1023-1027.

HöltJe, J. V. \& Tomasz, A. (1976). Purification of the pneumococcal $N$-acetyl-muramyl-L-alanine amidase to biochemical homogeneity. Journal of Biological Chemistry 251, 4199-4207.
LACKS, S. (1970). Mutants of Diplococcus pneumoniae that lack deoxyribonucleases and other activities possibly pertinent to genetic transformation. Journal of Bacteriology 101, 373-383.

Lopez, R., Ronda, C., Tomasz, A. \& Portoles, A. (1977). Properties of "diplophage": a lipidcontaining bacteriophage. Journal of Virology 24, 201-210.

Mosser, J. L. \& Tomasz, A. (1970). Choline containing teichoic acid as a structural component of pneumococcal cell wall and its role in sensitivity to lysis by an autolytic enzyme. Journal of Biological Chemistry 245, 287-298.

Ronda, C., Lopez, R., TAPIA, A. \& Tomasz, A. (1977). Role of the pneumococcal autolysin (murein hydrolase) in the release of progeny bacteriophage and in the bacteriophage-induced lysis of the host cells. Journal of Virology 21, 366-374.

TomAsz, A. (1966). A model for the mechanism controlling the expression of competent state in 
pneumococcus culture. Journal of Bacteriology 91, 1050-1061.

Tomasz, A. (1970). Cellular metabolism in genetic transformation of pneumococci: requirement for protein synthesis during induction of competence. Journal of Bacteriology 101, 860-871.

Tomasz, A. (1979). The mechanism of the irreversible antimicrobial effects of penicillins: how the betalactam antibiotics kill and lyse bacteria. Annual Review of Microbiology 33, 113-137.

TOMASZ, A. \& WAKs, S. (1975). Mechanism of action of penicillin: triggering of the pneumococcal autolytic enzyme by inhibitors of cell wall synthesis. Proceedings of the National Academy of Sciences of the United States of America 72, 4162-4166.

Tomasz, A., Westphal, M., Briles, E. B. \& Fletcher, P. (1975). On the physiological functions of teichoic acids. Journal of Supramolecular Structure 3, 1-16.

Weber, K., Pringle, J. R. \& Osborn, M. (1972). Measurement of molecular weights by electrophoresis on SDS-acrylamide gel. Methods in Enzymology 26C, 3-27. 